\title{
The effects of different plant extracts on bile salt hydrolase activity of Lactobacillus strains isolated from the gastrointestinal tract of poultry
}

\author{
Amin Dibamehr ${ }^{1}$, Mohsen Daneshyar ${ }^{1 *}$, Amir Tukmechi $^{2}$, and Seyyed Meysam Abtahi Froushani ${ }^{2}$ \\ ${ }^{I}$ Department of Animal Science, Faculty of Agriculture, Urmia University, Urmia, Iran \\ ${ }^{2}$ Department of Microbiology, Faculty of Veterinary Medicine, Urmia University, Urmia, Iran
}

DIBAMEHR, A., M. DANESHYAR, A. TUKMECHI, S. M. ABTAHI FROUSHANI: The effects of different plant extracts on bile salt hydrolase activity of Lactobacillus strains isolated from the gastrointestinal tract of poultry. Vet. arhiv 91, 89-99, 2021.

\section{ABSTRACT}

The bile salt hydrolysis (BSH) enzyme weakens fat metabolism through bile salt deconjugation and reduces poultry performance, in order to cope with the antibacterial properties of the bile. Therefore, reducing the activity of this enzyme through the use of feed additives is probably a promising alternative to antibiotics for improving poultry performance. Plant extracts have long been used as feed additives for promoting poultry growth. In the current experiment, five Lactobacillus strains including Lactobacillus animalis, Lactobacillus acidophillus, Lactobacillus gallinarum, Lactobacillus lactis, and Lactobacillus returi were obtained from the poultry hindgut and were used as the probiotic application. A plate test and two-step enzymatic reaction method were used for deconjugation activity determination of the Lactobacillus strains. Further, four plant extracts (i.e., the aerial parts of Rosemary (Rosmarinus officinalis), Roselle calyx (Hibiscus sabdariffa), Berberis vulgaris root, and Green tea) were examined in terms of BSH enzyme inhibitors using the cell-free extracts as the potential antibiotic alternative. Furthermore, the gallbladders of the broilers were freshly collected from the poultry slaughterhouses, and their contents were extracted. The results showed that all Lactobacillus strains could hydrolyze the taurocholate acid (TCA) and chicken bile salt mixture (CBSM) to unconjugated bile acid. Moreover, ethanolic extracts of $B$. vulgaris root and Green tea relatively reduced the activity of the BSH enzyme that could potentially be investigated as an appropriate alternative in poultry feed in vivo. In conclusion, all five Lactobacillus strains were resistant to bile salts (i.e. TCA and CBSM) by BSH activity, and the addition of Green tea and B. vulgaris root extracts to the bacterial medium demonstrated inhibitory effects against the BSH enzyme.

Key words: lactobacilli; bile salt hydrolase; plant extracts; antibiotic growth promoters

\section{Introduction}

For decades, antibiotic growth promoters (AGP) have been supplemented in poultry feed to improve the growth rate and feed conversion efficiency. Although the exact impacts of these supplementations are not completely recognized,

various ideas exist to clarify the principle of antibiotic-mediated growth improvement. The initial concept of AGP is associated with their antibacterial mode which decreases the total number of gut microbiota (FRANCOIS, 1961; VISEK,

\footnotetext{
*Corresponding author:

Assoc. Prof. Dr. Mohsen Daneshyar, Department of Animal Science, Faculty of Agriculture, Urmia University, P.O. Code: 5715944931, Urmia, Iran, Phone and Fax: +98 4432942 341; E-mail: m.daneshyar@urmia.ac.ir
} 
1978), leading to reduced competition for nutrients and microbial substances such as bile catabolism, which improves growth rate (FEIGHNER and DASHKEVICZ, 1987; GASKINS et al., 2002; KNARREBORG et al., 2004).

However, there is concern regarding the development of antibiotic-resistant strains of bacteria that could be considered as a potential hazard to humans and animals (MARON et al., 2013). The World Health Organization strongly supports restraint in AGP use and the European Union banned them entirely in 2006 (MARSHALL and LEVY, 2011). Therefore, researchers are interested in finding alternatives to AGP with a similar impact for poultry production (REID and FRIENDSHIP, 2002; COX and PAVIC, 2010). Although there are several groups of alternatives to AGP in the poultry industry, including probiotics, prebiotics, symbiotics, organic acids, enzymes and phytogenics (medicinal plants), a perfect alternative should have the same beneficial impacts of AGP and ensure the optimization of animal growth and performance (HUYGHEBAERT et al., 2011). Phytogenics, as an interesting group of feed additives, may be a potential alternative to AGP. The biological or therapeutic activity of a phytogenic is completely related to its bioactive compounds and properties, which are variable according their derivatives. On the basis of the plant's biological activity, its antioxidant properties, gut microflora manipulation and immune system improvement are the main modes of action by which phytogenics have a positive impact on the growth performance and health of animals (HASHEMI et al., 2009a, b; GUO et al., 2004).

Probiotic strains, such as Lactobacillus spp., are cultures of live microbes that have a beneficial impact on poultry performance by affecting the intestinal microbiota population (FULLER, 1989; SHOKRYAZDAN etal., 2017; HUANGetal., 2004).

However, a limited number of research experiments have investigated the microbiota products or enzymes that influence growth performance. Lactobacillus and Bifidobacterium as potent probiotics contain the BSH enzyme which catalyzes primary bile salt to secondary, and changes the host lipid metabolism. It is also known for reducing the level of cholesterol in serum through its direct impact on the host's bile salt metabolism (BEGLEY et al., 2006). For instance, $\mathrm{BSH}$ produced by lactobacilli, deconjugates the taurine and glycine of bile acids (LANGHOUT et al., 1999; BEGLEY et al., 2006), which decreases the formation of micelles (MACDONALD et al., 1983) and the performance of broilers subsequently (SHARIFI et al., 2012). According to the literature, the population of Lactobacillus strains, the major $\mathrm{BSH}$ producers in the chicken intestine, decreased in reaction to AGP (KNARREBORG et al., 2002; DUMONCEAUX et al., 2006; GUBAN et al., 2006; BEGLEY et al., 2006; ENGBERG et al., 2000). Therefore, AGPs may promote chicken performance by reducing BSH activity, as it is an enzyme that exerts a negative effect on host fat digestion and metabolism. Accordingly, the current study sought to evaluate the BSH activity of different Lactobacillus strains isolated from the chicken hindgut, as well as the inhibitory impact of different plant extracts as potential alternatives for AGP on the BSH activity of L. acidophillus. The decrease in the BSH activity of lactobacilli strains as probiotics is believed to promote their efficiency.

\section{Materials and methods}

Bacterial strains and culture conditions. Five Lactobacillus strains, including $L$. animalis, $L$. acidophillus, L. gallinarum, L. lactis and L. returi, were obtained from a microbiology laboratory (Urmia University, Iran), having been previously isolated from the gastrointestinal tract of the native chickens. The Lactobacillus strains were separately cultured in de Man, Rogosa and Sharpe (MRS) broth (Scharlau, Spain) and stored in 10\% glycerol at $-20{ }^{\circ} \mathrm{C}$ before use.

Preparation of CBSM. The gallbladders of broilers were freshly collected from poultry slaughterhouses, and the contents of the gallbladder were extracted, stored in an oven at $40{ }^{\circ} \mathrm{C}$, dried for 24 hours, and finally, powdered and autoclaved before use in bacterial cultures as CBSM.

Detection of bacterial BSH activity using the plate assay method. The bacteria were cultured in sterile MRS broth and incubated for 20 hours at 37 ${ }^{\circ} \mathrm{C}$ prior to checking the strains' BSH activity. The 
deconjugation of bile salt in Lactobacillus strains was qualitatively determined by the direct plate assay method with a slight modification (WANG et al., 2012). The MRS agar medium was enriched with bile salts $[0.5 \% \mathrm{w} / \mathrm{v}$, taurocholic acid, Fulka; $0.5 \%$ w/v CBSM and $\left.\mathrm{CaCl}_{2}(0.37 \mathrm{~g} / \mathrm{L})\right]$ and autoclaved before use. Next, bacterial cells were streaked onto the MRS agar plates and incubated at $37{ }^{\circ} \mathrm{C}$ for 5 days anaerobically. MRS agar medium plates were used as the control without supplementing TCA and CBSM. The presence of precipitated unconjugated bile acid around the bacterial colonies (opaque halo) for CBSM, and the formation of opaque granular shiny colonies on the agar indicated BSH activity specific for TCA.

Preparation of cell-free extracts (CFEs). BSH activity in the CFEs of each Lactobacillus strain was determined (LIONG and SHAH, 2005; TANAKA et al., 2000; DONG et al., 2012) with some modifications. First, the resting cell suspensions harvested from an overnight culture were centrifuged $\left(10,000 \times \mathrm{g}, 10 \mathrm{~min}\right.$ at $\left.4^{\circ} \mathrm{C}\right)$ and washed twice with $0.1 \mathrm{M}$ sodium phosphate buffer containing $10 \mathrm{mM}$ dithiothreitol (Merck; pH 7), and then resuspended in the same buffer to obtain a suspension with an optical absorbance $\left(\mathrm{A}_{600 \mathrm{~nm}}\right)$ of 3.0. Next, the cell pellet of each Lactobacillus strain was submitted to an ultrasonic homogenizer (Hielscher, Germany) for 5 min with a $50 \%$ duty circle at level 5 using $75 \%$ amplitude and constant cooling. Finally, the mixture was centrifuged for $10 \mathrm{~min}\left(20,000 \mathrm{~g}\right.$ at $\left.4{ }^{\circ} \mathrm{C}\right)$ and the supernatant was stored as a CFE at $-20^{\circ} \mathrm{C}$.

Colorimetric BSH assay. A two-step standard BSH assay (TANAKA et al., 2000) was performed to determine the BSH activity quantitatively with some modifications by the amount of amino acid released from the conjugated bile salts (TCA and CBSM) using Lactobacillus strains of CFEs. Briefly, $10 \mu \mathrm{L}$ of CFEs, $10 \mu \mathrm{L}$ of conjugated bile salts $(100 \mathrm{mM}$ TCA and 3\% w/v CBSM) were added to $180 \mu \mathrm{L}$ of reaction buffer $(0.1 \mathrm{M}$ sodiumphosphate, with a $\mathrm{pH}$ of 6.0 ). Then, the reaction mixture was conducted at $37{ }^{\circ} \mathrm{C}$ for $30 \mathrm{~min}$. Next, $200 \mu \mathrm{L}$ of $15 \%(\mathrm{w} / \mathrm{v})$ trichloroacetic acid was immediately added to stop the reaction, and the sample was centrifuged to remove the precipitates.
For the second reaction, the supernatant $(100 \mu \mathrm{L})$ was completely mixed with $1.9 \mathrm{~mL}$ of ninhydrin reagent $(0.5 \mathrm{~mL}$ of $1 \%(\mathrm{w} / \mathrm{v})$ ninhydrin in $0.5 \mathrm{M}$ sodium-citrate buffer with a $\mathrm{pH}$ of $5.5,0.2 \mathrm{~mL}$ of $0.5 \mathrm{M}$ sodium-citrate buffer with a $\mathrm{pH}$ of 5.5 , and $1.2 \mathrm{~mL}$ of glycerol), and the mixture was vortexed and boiled for $14 \mathrm{~min}$. After subsequent cooling for $3 \mathrm{~min}$ in tap water, the absorbance at $570 \mathrm{~nm}$ was determined using glycine or taurine as the standard. One unit of BSH activity $(\mathrm{U} / \mathrm{mL})$ was defined as the amount of enzyme that liberated $1 \mathrm{mmol}$ of amino acid from the substrate per min.

Microplate precipitation-based BSH activity assay. The fast evaluation of BSH determination is a precipitation-based check, through which the hydrolysis of the conjugated bile acid substance leads to deconjugated bile acids that are insoluble at the reaction $\mathrm{pH}$, and can easily be observed as a white precipitate (TANAKA et al., 2000; SMITH et al., 2014). Briefly, $10 \mu \mathrm{L}$ of CFEs was added to the wells of a 96-well microplate with a flat bottom. Then, $190 \mu \mathrm{L}$ of reaction mixture containing 178 $\mu \mathrm{L}$ of reaction buffer $(0.1 \mathrm{M}$ sodium-phosphate with a $\mathrm{pH}$ of 6.0$), 10 \mu \mathrm{L}$ of TCA $(100 \mathrm{mM})$, and $2 \mu \mathrm{L}$ of $1 \mathrm{M}$ dithiothreitol were added for a total reaction volume of $200 \mu \mathrm{L}$, to find out whether BSH positive activity in each strain in the wells became turbid immediately. In addition, the plates were incubated at $37{ }^{\circ} \mathrm{C}$ for up to 6 hours and the precipitation of insoluble unconjugated bile salts was monitored every $30 \mathrm{~min}$ by optical monitoring, concomitant to absorbance measurement at 600 $\mathrm{nm}\left(\mathrm{A}_{600 \mathrm{~nm}}\right)$ using a microplate reader (ELISA Reader Model DENA 3200). In order to assay BSH activity, different plant extracts with a serial dilution of stock concentrations were used as BSH inhibitor $(1 \%-0.015 \% \mathrm{v} / \mathrm{v})$ to find the best inhibitor. Before adding the reaction mixture, $10 \mu \mathrm{L}$ of the plant extracts was added to the $10 \mu \mathrm{L}$ CFEs of $L$. acidophillus in the bottom of each well and gently mixed by pipetting and incubated for $30 \mathrm{~min}$. Then, the reaction mixture was added and the precipitation of insoluble unconjugated bile salts was monitored every $30 \mathrm{~min}$ by optical monitoring, concomitant to absorbance measurement at $600 \mathrm{~nm}\left(\mathrm{~A}_{600 \mathrm{~nm}}\right)$ using a microplate reader (ELISA Reader Model DENA 3200). Subsequently, the potential BSH inhibitor 
candidates at various concentrations were checked through the above-mentioned two-step standard BSH assay based on precipitation using the 96-well microplate assay. Finally, the percentage inhibition was measured by dividing the inhibited activity (i.e., the mean activity of the control minus the mean residual activity in the presence of a plant extract) relative to the mean activity of the control and then multiplied by 100 .

Preparation of extracts. The plants (the aerial parts of Rosemary (Rosmarinus officinalis), Roselle calyx (Hibiscus sabdariffa), B. vulgaris root, and Green tea) were purchased, air-dried at room temperature, and ground to a mesh size of 1 $\mathrm{mm}$. Then, $100 \mathrm{~g}$ of each sample of the fine powder was dissolved in $1000 \mathrm{~mL}$ of $70 \%$ ethanol for $96 \mathrm{~h}$, followed by filtering and concentrating to a small volume in order to remove the entire ethanol using a rotary evaporator. The plant extracts were kept at $4{ }^{\circ} \mathrm{C}$ for further studies.

Gas chromatography-mass spectrometry (GC-MS) analysis of plant extracts. The extract contained both the polar and nonpolar components of the plant material, and $2 \mu \mathrm{L}$ of the sample of the solutions was used in GC-MS to analyze different compounds. The GC-MS analysis of the ethanol extract of the plant extract was performed using an Agilent 7890. A gas chromatograph coupled to a 5975A mass spectrometer was used with a HP-5 MS capillary column (5\% Phenyl Methyl polysiloxane, $30 \mathrm{~m}$ length, $0.25 \mathrm{~mm}$ i.d., $0.25 \mu \mathrm{m}$ film thickness).

The initial temperature of the oven was kept at 80 ${ }^{\circ} \mathrm{C}$ for three minutes and then increased at $8{ }^{\circ} \mathrm{C} / \mathrm{min}$ to $180^{\circ} \mathrm{C}$ and remained at the same temperature for 3 minutes. Further, helium was used as the carrier gas at a flow rate of $1 \mathrm{~mL} / \mathrm{min}$, the electron impact was $70 \mathrm{eV}$, the injector was set in a split mode (split ratio of 1:500), and mass range acquisition was from 40 to $500 \mathrm{~m} / \mathrm{z}$. Furthermore, the plant extract constituents were identified using the calculated linear retention indices (MONDELLO, 2008; NIST, 2005) and mass spectra were determined on the basis of those reported in NIST 05 . The relative percentage amount of each component was calculated by comparing its average peak area to the total area. Table 1 presents the phytochemicals present in plant extracts, qualitatively detected using standard screening tests.

\section{Results}

Qualitative BSH activity. In this experiment, different Lactobacillus strains (i.e., L. animalis, $L$. acidophillus, L. gallinarum, L. lactis, and L. returi) were qualitatively checked for BSH activity by direct plate assay. In general, as shown in Fig. 1, all Lactobacillus strains can hydrolyze TCA and CBSM to unconjugated bile acid which precipitates from the solid MRS medium. All five Lactobacillus strains produced the formation of characteristic precipitate halos around the colonies, and opaque granular shiny colonies on the agar.

Quantitative BSH activity. Table 2 shows the BSH activity of Lactobacillus strains on TCA and CBSM. In the quantitative assay, cell-free extracts obtained from Lactobacillus strains were tested for $\mathrm{BSH}$ activity in a two-step procedure, as previously described by TANAKA et al. (2000). Moreover, all the Lactobacillus strains demonstrated BSH activity towards TCA ranging from $4.06 \pm 0.057$ to $4.21 \pm 0.017 \mathrm{U} / \mathrm{mL}$ for $L$. acidophillus with the highest total of BSH activity units $(4.21 \pm 0.017)$, compared to L. animalis with the lowest total BSH activity $(\mathrm{U} / \mathrm{mL})$.

Moreover, Lactobacillus strains isolated from chicken indicate the ability to deconjugate CBSM. The BSH activity of these strains with respect to CBSM ranges from $3.78 \pm 0.015$ to $4.01 \pm 0.035$ $\mathrm{U} / \mathrm{mL}$. The lowest CBSM deconjugation activity $(3.78 \pm 0.015 \mathrm{U} / \mathrm{mL})$ is related to $L$. returi whereas the highest activity belongs to L. acidophillus and sodium taurocholate.

Microplate precipitation-based BSH activity assay. The BSH activity of each Lactobacillus strain was tested by microplate assay in different concentrations and types of the bile salts. However, the reaction mix in the wells (containing the bile salts and cell-free extracts) became turbid due to the precipitation of unconjugated bile salts by BSH activity. This was visualized by the naked eye as a white and yellow precipitate, and measured by a microplate reader. Then, different plant extracts, which are usually used as dietary supplements in 
poultry feeds, were added to identify their ability to decrease BSH activity. Various plant extracts, their inhibition activity, and the percentage inhibition effects of each extract are illustrated in Fig. 2.
Green tea and B. vulgaris root ethanol extracted showed a higher inhibitory effect on BSH activity than the others.

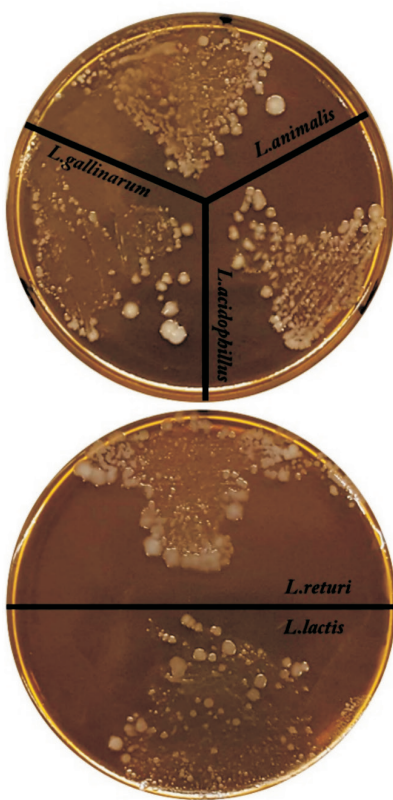

A
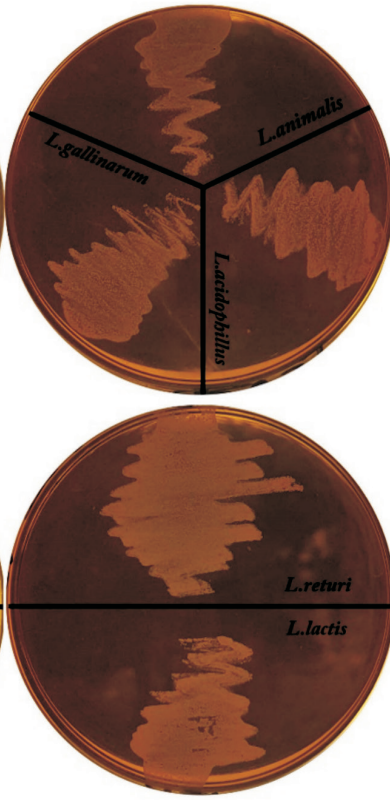

B
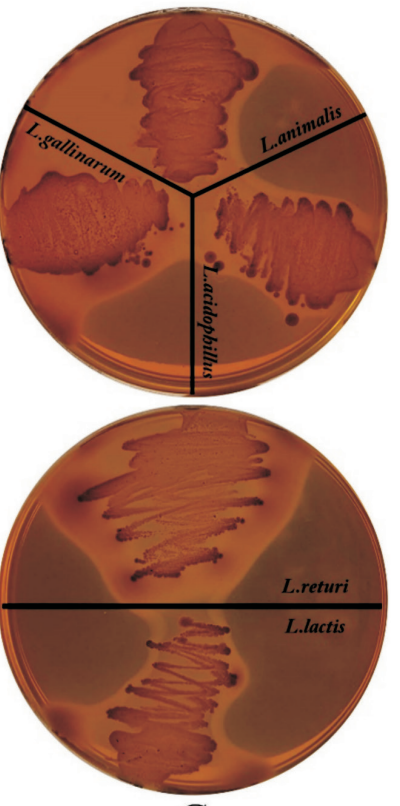

C

Fig. 1. The manifestation of BSH activity by lactobacilli on MRS agar medium. A, B, and C-labelled panels are control plates, assay plates containing $0.5 \% \mathrm{TCA}$, and assay plates containing $0.5 \% \mathrm{CBSM}$, respectively.

Table 1. Phytocomponents identified in ethanolic plant extracts by GC-MS

\begin{tabular}{|l|c|c|c|c|c|}
\hline \multicolumn{7}{|l|}{ Rosemary } \\
\hline Peak & $\begin{array}{c}\text { Retention } \\
\text { time }\end{array}$ & Area (\%) & $\begin{array}{c}\text { Molecular } \\
\text { weight }\end{array}$ & Compound name & Type/Nature \\
\hline 4 & 5.251 & 0.82 & $\mathrm{C}_{10} \mathrm{H}_{16}$ & $(1 \mathrm{R})$ - (+)-Alpha-Pinene & Terpene \\
\hline 5 & 7.282 & 15.51 & $\mathrm{C}_{10} \mathrm{H}_{18} \mathrm{O}$ & Eucalyptol & Monoterpenoid \\
\hline 8 & 9.909 & 3.99 & $\mathrm{C}_{10} \mathrm{H}_{16} \mathrm{O}$ & Camphor & Terpenoid \\
\hline 10 & 10.389 & 5.03 & $\mathrm{C}_{10} \mathrm{H}_{18} \mathrm{O}$ & Borneol & Monoterpenoid \\
\hline 12 & 10.864 & 0.49 & $\mathrm{C}_{9} \mathrm{H}_{14} \mathrm{O}$ & 4-isopropyl-2-cyclohexenone & Cryptone \\
\hline 15 & 11.711 & 3.92 & $\mathrm{C}_{6} \mathrm{H}_{6} \mathrm{O}_{3}$ & furfural & Hydroxymethyl \\
\hline 19 & 16.472 & 33.49 & $\mathrm{C}_{9} \mathrm{H}_{6} \mathrm{O}_{2}$ & 2H-1-Benzopyran-2-one & Coumarin \\
\hline 25 & 22.148 & 9.82 & $\mathrm{C}_{10} \mathrm{H}_{8} \mathrm{O}_{3}$ & 7-Methoxy-2H-1benzopyran-2 one & Herniarin \\
\hline 27 & 26.434 & 0.89 & $\mathrm{C}_{16} \mathrm{H}_{32} \mathrm{O}_{2}$ & n-Hexadecoic acid & Palmitinic acid \\
\hline 28 & 28.431 & 3.08 & $\mathrm{C}_{20} \mathrm{H}_{40} \mathrm{O}$ & Phytol & Diterpene \\
\hline
\end{tabular}


A. Dibamehr et al.: Plant extracts on Lactobacillus strains in poultry

Table 1. Phytocomponents identified in ethanolic plant extracts by GC-MS (continued)

\begin{tabular}{|c|c|c|c|c|c|}
\hline \multicolumn{6}{|c|}{ B. vulgaris } \\
\hline 1 & 2.156 & 1.31 & $\mathrm{C}_{7} \mathrm{H}_{14}$ & cis-1,3-Dimethyl cyclopentane & Cyclopentane \\
\hline 2 & 2.190 & 1.80 & $\mathrm{C}_{7} \mathrm{H}_{14}$ & 1,2-dimethyl-Cyclopentane & Cyclopentane \\
\hline 11 & 9.789 & 3.67 & $\mathrm{C}_{6} \mathrm{H}_{8} \mathrm{O}_{4}$ & $\begin{array}{l}\text { 4H-Pyran-4-one, 2,3 dihydro-3,5- } \\
\text { dihydroxy-6-methyl }\end{array}$ & \\
\hline 12 & 13.737 & 16.83 & $\mathrm{C}_{9} \mathrm{H}_{10} \mathrm{O}_{2}$ & 2-Methoxy-4-vinylphenol & Guaiacol \\
\hline 23 & 24.506 & 10.95 & $\mathrm{C}_{12} \mathrm{H}_{16} \mathrm{O}_{4}$ & $\begin{array}{l}\text { 2-(3,4-Dimethoxyphenyl) } \\
\text { tetrahydropyran }\end{array}$ & Elemicin \\
\hline 24 & 26.434 & 1.55 & $\mathrm{C}_{16} \mathrm{H}_{32} \mathrm{O}_{2}$ & n-Hexadecanoic acid & Palmitinic acid \\
\hline \multicolumn{6}{|c|}{ Green tea } \\
\hline 10 & 13.594 & 0.53 & $\mathrm{C}_{11} \mathrm{H}_{18} \mathrm{O}_{2}$ & 2,6-Octadien-1-ol, 3,7-dimethyl- acetate & Geranyl acetate \\
\hline 13 & 15.024 & 3.87 & $\mathrm{C}_{6} \mathrm{H}_{6} \mathrm{O}_{3}$ & 1,2,3-Benzenetriol & Pyrogallol \\
\hline 21 & 24.786 & 76.96 & $\mathrm{C}_{8} \mathrm{H}_{10} \mathrm{~N}_{4} \mathrm{O}_{2}$ & Caffeine & Alkaloid \\
\hline 22 & 25.038 & 1 & $\mathrm{C}_{7} \mathrm{H}_{8} \mathrm{~N}_{4} \mathrm{O}_{2}$ & Theobromine & Alkaloid \\
\hline 23 & 26.434 & 0.85 & $\mathrm{C}_{16} \mathrm{H}_{32} \mathrm{O}_{2}$ & n-Hexadecanoic acid & Palmitinic acid \\
\hline 24 & 28.431 & 3.04 & $\mathrm{C}_{20} \mathrm{H}_{40} \mathrm{O}$ & Phytol & Diterpene \\
\hline \multicolumn{6}{|c|}{ Roselle calyx } \\
\hline 1 & 2.155 & 0.41 & $\mathrm{C}_{7} \mathrm{H}_{14}$ & 1,3-dimethyl-cyclopentane & Cyclopentane \\
\hline 3 & 3.597 & 2.94 & $\mathrm{C}_{5} \mathrm{H}_{4} \mathrm{O}_{2}$ & 2-Furaldehyde & Furfural \\
\hline 5 & 5.818 & 0.69 & $\mathrm{C}_{7} \mathrm{H}_{6} \mathrm{O}_{4}$ & Methyl-5-formylfuran & \\
\hline 10 & 9.789 & 0.43 & $\mathrm{C}_{6} \mathrm{H}_{8} \mathrm{O}_{4}$ & $\begin{array}{l}\text { 4H-Pyran-4-one,2,3-dihydro-3,5- } \\
\text { dihydroxy-6-methyl }\end{array}$ & \\
\hline 15 & 11.774 & 5.01 & $\mathrm{C}_{6} \mathrm{H}_{6} \mathrm{O}_{3}$ & Hydroxymethylfurfurole & Levulinic acid \\
\hline 26 & 26.451 & 1.13 & $\mathrm{C}_{16} \mathrm{H}_{32} \mathrm{O}_{2}$ & n-Hexadecoic acid & Palmitinic acid \\
\hline 29 & 28.980 & 1.68 & $\mathrm{C}_{18} \mathrm{H}_{32} \mathrm{O}_{2}$ & 9,12-Octadecadienoic acid & $\begin{array}{l}\text { Linoleic acid ethyl } \\
\text { ester }\end{array}$ \\
\hline 30 & 29.054 & 1.16 & $\mathrm{C}_{20} \mathrm{H}_{36}$ & Ethyl linoleolate & Linoleic acid \\
\hline
\end{tabular}

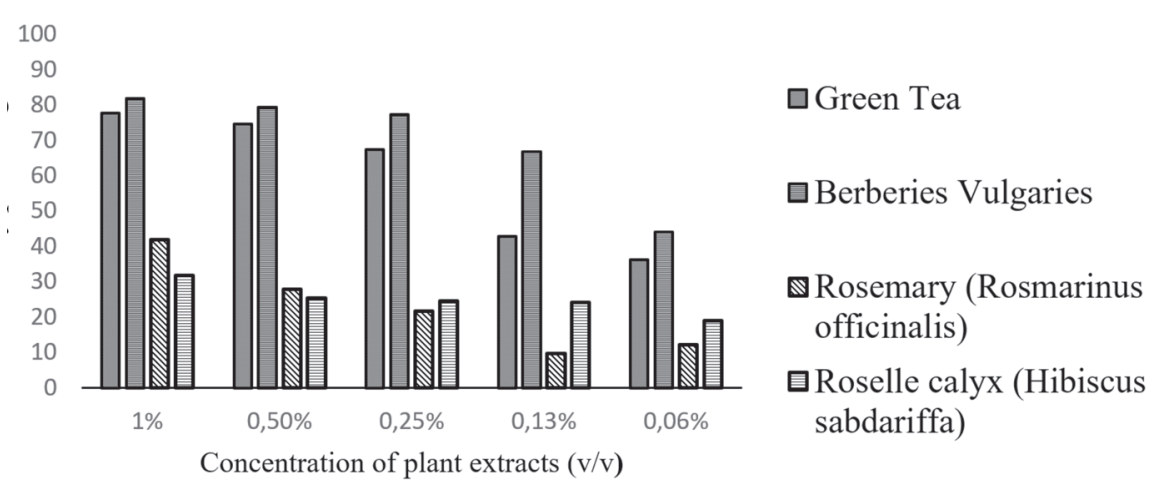

Fig. 2. Percentage inhibition of different plant extracts on BSH enzyme 
Table 2. BSH Activity of Lactobacillus Strains on TCA and CBSM ${ }^{2}$

\begin{tabular}{|l|c|c|}
\hline \multirow{2}{*}{ Strains } & \multicolumn{2}{|c|}{ BSH Activity $^{1}$} \\
\cline { 2 - 3 } & Total activity $(\mathrm{U} / \mathrm{mL})$ of $\mathrm{CBSM}^{3}$ & Total activity $(\mathrm{U} / \mathrm{mL})$ of TCA $^{3}$ \\
\hline L. animalis & $3.94 \pm 0.032$ & $4.13 \pm 0.026$ \\
\hline L. lactis & $4.01 \pm 0.058$ & $4.19 \pm 0.005$ \\
\hline L. gallinarum & $3.96 \pm 0.020$ & $4.17 \pm 0.021$ \\
\hline L. acidophillus & $4.01 \pm 0.35$ & $4.21 \pm 0.017$ \\
\hline L. returi & $3.78 \pm 0.015$ & $4.06 \pm 0.057$ \\
\hline
\end{tabular}

${ }^{1}$ The results are provided as means \pm standard deviation; the values are in triplicate; ${ }^{2} \mathrm{BSH}$ activity from cell-free extracts of Lactobacillus strains grown on MRS broth supplemented with $3 \% \mathrm{w} / \mathrm{v}$ CBSM and $100 \mathrm{mM} \mathrm{TCA} ;{ }^{3} \mathrm{CBSM}$ : Chicken bile salt mixture; TCA: Taurocholic acid.

\section{Discussion}

The most important trait of probiotics is to survive while passing through the gastrointestinal tract in order to preserve their beneficial impacts (ELLI et al., 2006). Many parameters such as gastrointestinal $\mathrm{pH}$, bile salts, and others may influence the survival capability of the probiotic. The exact beneficial effects of the BSH enzyme in probiotic bacteria such as lactobacilli and bifidobacteria (BEGLEY et al., 2006) are still not well recognized. But there are some hypothesizes about the roles of BSH in bacterial physiology based on some evidence related to certain commensal bacteria and conjugated bile salts (GENG and LIN, 2016). It has been demonstrated that hydrolysis of conjugated bile acids via BSH could supply cellular carbon, nitrogen, sulfur and energy source for some bacteria species (VLAHCEVIC et al., 1996; TANAKA et al., 2000; RIDLON et al., 2006).

Moreover, the presence of conjugated bile salts in the environment of the small intestine, is the most unfavorable and toxic parameter to the survival of probiotics (BEZKOROVAINY, 2001). Thus, the ability of probiotic Lactobacilli to detoxify bile salts through the production of the BSH enzyme is often included among the criteria for probiotic strain selection (NORIEGA et al., 2006). Furthermore, Lactobacillus strains isolated from the gastrointestinal tract are more likely to be BSH positive than those without exposure to bile salts (TANAKA et al., 1999). In the present study, all the Lactobacillus strains isolated from the gastrointestinal tract of chickens clearly revealed BSH activity for TCA and CBSM through the direct plate and quantitative assays in the current experiment.

$\mathrm{BSH}$ is an enzyme that changes the state of conjugated bile salt to unconjugated and free primary bile acids (GILLILAND and SPECK, 1977). Therefore, BSH enzyme in probiotic bacteria could have reciprocal impacts on the host physiology by disturbing conjugated bile acidmediated fat metabolism and endocrine functions (JONES et al., 2014; JOYCE et al., 2014). Hence, these abilities of the BSH enzyme are associated with reduced serum cholesterol levels, and are gaining much more attention in human patients. To date, limited research has been conducted about the BSH activities of intestinal bacterial on animal performance (FEIGHNER and DASHKEVICZ, 1987; GUBAN et al., 2006; LIN, 2014).

However, some investigations have indicated that probiotic supplementation to broiler diets weakens performance by reducing fat digestibility that can have an undesirable effect on animal production (MOUNTZOURIS et al., 2010; SHARIFI et al., 2012). Additionally, several researchers have reported a correlation between BSH activity in the intestine and AGP, and concluded that using AGP leads to a reduction in BSH activity, and improves animal growth performance by higher fat digestibility (GUBAN et al., 2006; FEIGHNER and DASHKEVICZ, 1987). In addition, others indicate 
that conjugated bile acids play a crucial role in lipid digestion and micelle formation (DIBNER and RICHARDS, 2005; BEGLEY et al., 2006).

Similarly, AGP have been used in animal nutrition for more than 60 years, to improve the growth rate and feed conversion ratio while preventing infections (CASTANON, 2007). Despite the important positive effects of AGP on growth rate, mortality and higher disease resistance, these types of additives have a number of disadvantages. These concerns include the development of antimicrobial resistance, which is a potential threat to human health (WHO, 2012). According to LIN et al. (2014) there is an inverse relationship between BSH activity as a potent characteristic of bacteria in the intestine and body weight gain.

Therefore, reducing BSH activity in bacteria by BSH inhibitors could be one of the main objectives for developing novel alternatives to AGP. WANG et al. (2012) recommended that research on BSH enzyme activity can be the main mechanistic microbiome target for new alternatives to AGPs, and hence scientists have focused on a potent BSH enzyme from a chicken $L$. salivarius probiotic strain, to find BSH inhibitors as alternatives to AGPs (GENG and LIN, 2016). They have suggested some chemical compounds as BSH inhibitors, such as copper and zinc in high dosages which were known growth promoters in poultry nutrition in the past (LIU et al., 2011; WANG et al., 2012). However, there are some undesirable effects of these kinds of metals being used long-term in animal feed as growth promoters, such as toxicosis due to extended exposure and soil pollution via increased amounts excreted in the feces.

In this study, B. vulgaris root and Green tea extracts had a high inhibitory effect on BSH activity in L. acidophilus. LIN et al. (2014) discovered some potent BSH inhibitors for a phylogenetically distant BSH from L. acidophilus. SMITH et al. (2014) considered more than 2000 compounds as BSH inhibitors by high-throughput screening technology, and suggested some natural and chemical substances as potential alternatives to AGP. These studies recommended that Carnosic acid (the most bioactive compound of Rosemary), epichatechin monogallate (the most bioactive compound of
Green tea), and gossypetin (the most bioactive compound of Roselle calyx) were potential natural BSH inhibitors. Therefore, more investigations will be needed into modified designs of probiotics based on BSH and BSH-producing bacteria, to decrease the detrimental effects of BSH on fat digestibility and energy harvesting, and hence conserve the other valuable impacts of probiotics on animal health and the immune system. Furthermore, this will help to develop safe BSH inhibitor-based, non-antibiotic feed additives for improving feed efficiency and growth rate.

\section{Conclusion}

In general, this study found that all five Lactobacillus strains isolated from the native poultry hindgut were resistant to bile salts (i.e., TCA and CBSM) throughout BSH activity. Among the plant extracts of the present study, Green tea and B. vulgaris root showed relative inhibitory effects against the BSH enzyme. Therefore, these plant extracts could be regarded as potential alternatives to AGP, along with the lactobacilli as probiotics that may result in improving poultry production by harvesting the energy of increased fat digestibility, and also providing advantages for health status.

\section{References}

BEGLEY, M., C. HILL, C. G. GAHAN (2006): Bile salt hydrolase activity in probiotics. Appl. Environ. Microbiol. $72,1729-1738$.

DOI: 10.1128/AEM.72.3.1729-1738.2006

BEZKOROVAINY, A. (2001): Probiotics: determinants of survival and growth in the gut. Am. J. Clin. Nutr. 73, 399S-405S.

DOI: $10.1093 / \mathrm{ajcn} / 73.2 .399 \mathrm{~s}$

CASTANON, J. I. R. (2007): History of the use of antibiotic as growth promoters in European poultry feeds. Poult. Sci. 86, 2466-2471.

DOI: $10.3382 /$ ps.2007-00249

COX, J. M., A. PAVIC (2010): Advances in enteropathogen control in poultry production. J. Appl. Microbiol. 108, 745755.

DOI: $10.1111 / \mathrm{j} .1365-2672.2009 .04456 . \mathrm{x}$

DIBNER, J. J., J. D. RICHARDS (2005): Antibiotic growth promoters in agriculture: history and mode of action. Poult. Sci. 84, 634-643.

DOI: $10.1093 / \mathrm{ps} / 84.4 .634$ 
DONG, Z., J. ZHANG, B. LEE, H. LI, G. DU, J. CHEN (2012): A bile salt hydrolase gene of Lactobacillus plantarum BBE7 with high cholesterol-removing activity. Eur. Food Res. Technol. 235, 419-427.

DOI: $10.1007 / \mathrm{s} 00217-012-1769-9$

DUMONCEAUX, T. J., J. E. HILL, S. M. HEMMINGSEN, A.G. VAN KESSEL (2006): Characterization of intestinal microbiota and response to dietary virginiamycin supplementation in the broiler chicken. Appl. Environ. Microbiol. 72, 2815-2823.

DOI: 10.1128/AEM.72.4.2815-2823.2006

ELLI, M., M. L. CALLEGARI, S. FERRARI, E. BESSI, D. CATTIVELli, S. SOLDI, L. MORELli, N. G. FEUILLERAT, J. M. ANTOINE (2006): Survival of yogurt bacteria in the human gut. Appl. Environ. Microbiol. 72, 5113-5117.

DOI: 10.1128/AEM.02950-05

ENGBERG, R. M., M. S. HEDEMANN, T. D. LESER, B. B. JENSEN (2000): Effect of zinc bacitracin and salinomycin on intestinal microflora and performance of broilers. Poult. Sci. 79, 1311-1319.

DOI: $10.1093 / \mathrm{ps} / 79.9 .1311$

FEIGHNER, S. D., M. P. DASHKEVICZ (1987): Subtherapeutic levels of antibiotics in poultry feeds and their effects on weight gain, feed efficiency and bacterial cholyltaurine hydrolase activity. Appl. Environ. Microbiol. 53, 331-336.

DOI: 10.1128/AEM.53.2.331-336.1987

FRANCOIS, A. C. (1961): Mode of action of antibiotics on growth. World Rev. Nutr. Diet. 3, 21-64.

FULLER, R. (1989). Probiotics in man and animals. J. Appl. Bacteriol. 66, 365-378.

DOI: $10.1111 / j .1365-2672.1989 . t b 05105 . x$

GASKINS, H. R., C. T. COLLIER, D. B. ANDERSON (2002): Antibiotics as growth promotants: mode of action. Anim. Biotechnol. 13, 29-42.

DOI: $10.1081 / \mathrm{ABIO}-120005768$

GILLILAND, S. E., M. L. SPECK (1977): Deconjugation of bile acids by intestinal lactobacilli. Appl. Environ. Microbiol. 33, 15-18.

DOI: 10.1128/AEM.33.1.15-18.1977

GENG, W., J. LIN (2016): Bacterial bile salt hydrolase: An intestinal microbiome target for enhanced animal health. Anim. Health Res. Rev. 17, 148-158.

DOI: $10.1017 / \mathrm{S} 1466252316000153$

GUBAN, J., D. R. KORVER, G. E. ALLISON, G. W. TANNOCK (2006): Relationship of dietary antimicrobial drug administration with broiler performance, decreased population levels of Lactobacillus Salivarius, and reduced bile salt deconjugation in the ileum of broiler chickens. Poult. Sci. 85, 2186-2194.

DOI: $10.1093 / \mathrm{ps} / 85.12 .2186$
GUO, F. C., B. A. WILLIAMS, R. P. KWAKKEL, H. S. LI, X. P. LI, J. Y. LUO, W. K. LI, M. W. VERSTEGEN (2004): Effects of mushroom and herb polysaccharides, as alternatives for an antibiotic, on the cecal microbial ecosystem in broiler chickens. Poult. Sci. 83, 175-182.

DOI: $10.1093 / \mathrm{ps} / 83.2 .175$

HASHEMI, S. R., I. ZULKIFLI, M. HAIR-BEJO, M. KARAMI, A. F. SOLEIMANI (2009a): The effects of Euphorbia hirta and acidifier supplementation on growth performance and antioxidant activity in broiler chickens. In: Proceedings of the $21^{\text {st }}$ Veterinary Association Malaysia (VAM) Congress, August 2009, Port Dickson, Malaysia, pp. 215-217.

HASHEMI, S. R., I. ZULKIFLI, Z. ZUNITA, M. HAIR-BEJO, T. C. LOH, M. N. SOMCHIT, P. C. KOK, H. DAVOODI (2009b): Effects of dietary supplementation with Euphorbia hirta and acidifier on performance and Salmonella colonization in broiler chickens. In: Proceedings of the $30^{\text {th }}$ Malaysia Society of Animal Production Annual Conference, June 2009, Kota Kinabalu, Malaysia, pp. 6970.

HUANG, M. K., Y. J. CHOI, R. HOUDE, J. W. LEE, B. LEE, X. ZHAO (2004): Effects of lactobacilli and an acidophilic fungus on the production performance and immune responses in broiler chickens. Poult. Sci. 83, 788-795.

DOI: $10.1093 / \mathrm{ps} / 83.5 .788$

HUYGHEBAERT, G., R. DUCATELLE, F. VAN IMMERSEEL (2011): An update on alternatives to antimicrobial growth promoters for broilers. Vet. J. 187, 182-188.

DOI: 10.1016/j.tvj1.2010.03.003

JONES, M. L., C. J. MARTONI, J. G. GANOPOLSKY, A. LABBÉ, S. PRAKASH (2014): The human microbiome and bile acid metabolism: dysbiosis, dysmetabolism, disease and intervention. Expert Opin. Biol. Ther. 14, 467482.

DOI: $10.1517 / 14712598.2014 .880420$

JOYCE, S. A., F. SHANAHAN, C. HILL C. G. GAHAN (2014). Bacterial bile salt hydrolase in host metabolism: potential for influencing gastrointestinal microbe-host crosstalk. Gut Microbes 5, 669-674.

DOI: 10.4161/19490976.2014.969986

KNARREBORG, A., C. LAURIDSEN, R. M. ENGBERG, S. K. JENSEN (2004): Dietary antibiotic growth promoters enhance the bioavailability of alpha-tocopheryl acetate in broilers by altering lipid absorption. J. Nutr. 134, 1487 1492.

DOI: $10.1093 / \mathrm{jn} / 134.6 .1487$

KNARREBORG, A., M. A. SIMON, R. M. ENGBERG, B. B. JENSEN, G. W. TANNOCK (2002): Effects of dietary fat source and subtherapeutic levels of antibiotic on the bacterial community in the ileum of broiler chickens at various ages. Appl. Environ. Microbiol. 68, 5918-5924.

DOI: 10.1128/AEM.68.12.5918-5924.2002 
LANGHOUT, D. J., J. B. SCHUTTE, P. VAN LEEUWEN, J. WIEBENGA, S. TAMMINGA (1999): Effect of dietary high- and low- methylated citrus pectin on the activity of the ileal microflora and morphology of the small intestinal wall of broiler chick. Br. Poult. Sci. 40, 340-347.

DOI: $10.1080 / 00071669987421$

LIN, J. (2014): Antibiotic growth promoters enhance animal production by targeting intestinal bile salt hydrolase and its producers. Front. Microbiol. 5, 33.

DOI: $10.3389 /$ fmicb.2014.00033

LIONG, M. T., N. P. SHAH (2005): Bile salt deconjugation ability, bile salt hydrolase activity and cholesterol coprecipitation ability of lactobacilli strains. Int. Dairy J. 15, 391-398.

DOI: 10.1016/j.idairyj.2004.08.007

LIU, Z. H., L. LU, S. F. LI, L. Y. ZHANG, L. XI, K. Y. ZHANG, X. G. LUO (2011): Effects of supplemental zinc source and level on growth performance, carcass traits, and meat quality of broilers. Poult. Sci. 90, 1782-1790.

DOI: $10.3382 /$ ps.2010-01215

MACDONALD, I. A., V. D. BOKKENHEUSER, J. WINTER, A. M. MCLERNON, E. H. MOSBACH (1983): Degradation of steroids in the human gut. J. Lipid Res. 24, 675-700.

DOI: 10.1016/S0022-2275(20)37944-X

MARON, D. F., T. J. SMITH, K. E. NACHMAN (2013): Restrictions on antimicrobial use in food animal production: an international regulatory and economic survey. Global Health. 9, 48.

DOI: $10.1186 / 1744-8603-9-48$

MARSHALL, B. M., S. B. LEVY (2011): Food animals and antimicrobials: impacts on human health. Clin. Microbiol. Rev. 24, 718-733.

DOI: $10.1128 / C M R .00002-11$

MONDELLO, L. (2008): Mass spectra of flavors and fragrances of natural and synthetic compounds. CD. 2008 ed, Wiley, New York.

MOUNTZOURIS, K. C., P. TSITRSIKOS, I. PALAMIDI, A. ARVANITI, M. MOHNL, G. SCHATZMAYR, K. FEGEROS (2010): Effects of probiotic inclusion levels in broiler nutrition on growth performance, nutrient digestibility, plasma immunoglobulins, and cecal microflora composition. Poult. Sci. 89, 58-67.

DOI: 10.3382/ps.2009-00308

NIST (National Institute of Standards and Technology) (2005): NIST/EPA/NIH mass spectral library and the NIST mass spectral search program, NIST, 2005 ed. Gaithersburg, MD.

NORIEGA, L., I. CUEVAS, A. MARGOLLES, C. G. DE LOS REYES-GAVILAN (2006): Deconjugation and bile salts hydrolase activity by Bifidobacterium strains with acquired resistance to bile. Int. Dairy J. 16, 850-855.

DOI: 10.1016/j.idairyj.2005.09.008
REID, G., R. FRIENDSHIP (2002): Alternatives to antibiotic use: Probiotics for the gut. Anim. Biotechnol. 13, 97-112. DOI: 10.1081/ABIO-120005773

RIDLON, J. M., D. J. KANG, P. B. HYLEMON (2006): Bile salt biotransformations by human intestinal bacteria. J. Lipid Res. 47, 241-259.

DOI: 10.1194/j1r.R500013-JLR200

SHARIFI, S. D., A. DIBAMEHR, H. LOTFOLLAHIAN, B. BAURHOO (2012): Effects of flavomycin and probiotic supplementation to diets containing different sources of fat on growth performance, intestinal morphology, apparent metabolizable energy, and fat digestibility in broiler chickens. Poult. Sci. 91, 918-927.

DOI: $10.3382 /$ ps.2011-01844

SHOKRYAZDAN, P., M. FASELEH JAHROMI, J. B. LIANG, K. RAMASAMY, C. C. SIEO, Y. W. HO (2017): Effects of a Lactobacillus salivarius mixture on performance, intestinal health and serum lipids of broiler chickens. PLoS One. 12,5 , e0175959.

DOI: 10.1371/journal.pone.0175959

SMITH, K., X. ZENG, J. LIN (2014). Discovery of bile salt hydrolase inhibitors using an efficient high-throughput screening system. PloS One. 9, 1, e85344.

DOI: 10.1371/journal.pone.0085344

TANAKA H., K. DOESBURG, T. IWASAKI, I. MIERAU (1999): Screening of lactic acid bacteria for bile salt hydrolase activity. J. Dairy Sci. 82, 2530-2535.

DOI: 10.3168/jds.S0022-0302(99)75506-2

TANAKA, H., H. HASHIBA, J. KOK, I. MIERAU (2000): Bile salt hydrolase of Bifidobacterium longum-biochemical and genetic characterization. Appl. Environ. Microbiol. 66, 2502-2512.

DOI: 10.1128/AEM.66.6.2502-2512.2000

VISEK, W. J. (1978): The mode of growth promotion by antibiotics. J. Anim. Sci. Technol. 46, 1447-1469. DOI: $10.2527 /$ jas $1978.4651447 \mathrm{x}$

VLAHCEVIC, Z. R., D. M. HEUMAN, P. B. HYLEMON (1996). Physiology and pathophysiology of enterohepatic circulation of bile acids. In Hepatology: a textbook of liver disease. 3rd ed., Vol. 1., Edited by D. Zakim, T. Boyer. Saunders, Philadelphia, pp. 376-417.

WANG, Z., X. ZENG, Y. MO, K. SMITH, Y. GUO, J. LIN (2012): Identification and characterization of a bile salt hydrolase from Lactobacillus salivarius for development of novel alternatives to antibiotic growth promoters. Appl. Environ. Microbiol. 78, 8795-8802.

DOI: 10.1128/AEM.02519-12

WORLD HEALTH ORGANIZATION (2012): The evolving threat of antimicrobial resistance: options for action. World Health Organ. http://www.who.int/iris/ handle/10665/44812. 
A. Dibamehr et al.: Plant extracts on Lactobacillus strains in poultry

Received: 28 November 2019

Accepted: 20 August 2020

DIBAMEHR, A., M. DANESHYAR, A. TUKMECHI, S. M. ABTAHI FROUSHANI: Učinak različitih biljnih ekstrakata na aktivnost hidrolaze žučnih soli sojeva bakterije Lactobacillus izolirane iz probavnog sustava peradi. Vet. arhiv 91, 89-99, 2021.

\section{SAŽETAK}

Enzimi hidrolaze žučnih soli (BSH) oslabljuju metabolizam masti dekonjugacijom žučnih soli što dovodi do smanjenja proizvodnosti u peradi. Smanjenje aktivnosti ovog enzima, upotrebom dodataka prehrani, mogla bi biti obećavajuća alternativa za primjenu određenih antibiotika u peradarstvu. Biljni ekstrakti dugo se upotrebljavaju kao dodaci prehrani za poticanje rasta. U ovom je istraživanju pet sojeva bakterije Lactobacillus, uključujući Lactobacillus animalis, Lactobacillus acidophillus, Lactobacillus gallinarum, Lactobacillus lactis i Lactobacillus returi, dobiveno iz stražnjeg dijela crijeva peradi te upotrijebljeno kao probiotik. Test na ploči i enzimska reakcija u dva koraka primijenjene su za utvrđivanje aktivnosti dekonjugacije u sojeva Lactobacillus. Nadalje, četiri biljna ekstrakta nadzemni dijelovi ružmarina (Rosmarinus officinalis), hibiskusa (Hibiscus sabdariffa), korijen obične žutike (Berberis vulgaris) i zeleni čaj - istraživana su s obzirom na inhibitore enzima BSH upotrebom izvanstaničnih ekstrakata kao moguća zamjena antibiotiku. Osim toga, nakon usmrćivanja, prikupljeni su svježi žučni mjehuri brojlera te je izvađen njihov sadržaj. Rezultati su pokazali da svi sojevi bakterije Lactobacillus mogu hidrolizirali tauroholatnu kiselinu i žučne soli pilića (CBSM) u nekonjugiranu žučnu kiselinu. Štoviše, ekstrakti etanola korijena B. vulgaris i zelenog čaja relativno su smanjili aktivnost BSH enzima što bi se moglo istražiti u hranidbi peradi in vivo. Zaključno, svih pet sojeva bakterije Lactobacillus bilo je otporno na žučne soli npr. tauroholičnu kiselinu (TCA) i (CBSM) putem BSH aktivnosti, a dodatak zelenog čaja i ekstrakta korijena $B$. vulgaris mediju s bakterijama pokazali su inhibitorne učinke protiv BSH enzima.

Ključne riječi: laktobacili; hidrolaza žučnih soli; biljni ekstrakti; antibiotici kao promotori rasta 
